\title{
Phenotypic and Molecular Dissection of Induced Groundnut Mutants for Fatty Acid Profile
}

\author{
Kavera Biradar ${ }^{1}$, Mallikarjun Kenganal ${ }^{2 *}$ and H.L. Nadaf ${ }^{1}$ \\ ${ }^{1}$ Department of Genetics and Plant Breeding, University of Agricultural Sciences, \\ Dharwad, Karnataka, India \\ ${ }^{2}$ Department of Plant Pathology, University of Agricultural Sciences, Raichur, Karnataka, India \\ *Corresponding author
}

\begin{tabular}{|l|}
\hline Ke y w o r d s \\
Groundnut, Fatty \\
acids, Mutants, \\
RAPD, \\
Polymorphism, \\
Molecular markers. \\
\hline Article Info \\
\hline $\begin{array}{l}\text { Accepted: } \\
23 \text { October } 2017 \\
\text { Available Online: } \\
\text { 10 December } 2017\end{array}$
\end{tabular}

A B S T R A C T

Fatty acid composition of groundnut oil is an important trait from the point of human nutrition and oil stability during storage. Breeding groundnut for enhanced oil quality includes the development of cultivars with high oleic and low linoleic acid. In India, availability of breeding lines to improve groundnut oil quality is limited. Induction of genetic variability for fatty acid composition is desired and is a prerequisite in groundnut for its genetic improvement. The present work was undertaken to induce genetic variability for fatty acid profile using chemical (ethyl methanesulfonate) and physical (gamma rays) mutagens in two groundnut cultivars viz., GPBD-4 and TPG41. In the $\mathrm{M}_{5}$ generation among the eight fatty acids studied, a greater magnitude of induced variation was observed for palmitic acid, oleic acid, linoleic acid and oleic/linoleic acid ratio $(\mathrm{O} / \mathrm{L})$. The induced variability was skewed towards high levels of oleic acid and low level of linoleic acid in GPBD-4. The EMS (0.5\%) mutagen treatment in GPBD-4 resulted in higher magnitude of variability for oleic acid (39.0175.16), linoleic acid (9.01-37.82) and O/L (1.03-8.34). However in TPG-41 the induced variability was skewed towards higher linoleic acid and low oleic acid with the mutagen treatment 200 Gy exhibiting greater range values for oleic acid (37.4064.55), linoleic acid (16.53-38.33) and O/L (0.95-3.91). Further marker-assisted selection would be particularly valuable for use in improvement of the fatty acid profile of groundnut. Random amplified polymorphic DNA (RAPD) techniques were investigated for the development of molecular markers for genes controlling oleic and/or linolenic acid. A total number of 22 distinct mutants identified for fatty acid composition were assessed for molecular diversity using RAPD assay along with their respective parents revealed limited polymorphism. The RAPD marker OPAT 02 accounted for highest per cent polymorphism (80). High O/L types identified from mutant populations of both the genotypes were grouped into the same cluster suggesting close molecular relationship between them. Mutant GE-273 characterized by low $\mathrm{O} / \mathrm{L}$ ratio (1.16) compared to parent, GPBD-4 (1.76) produced a very distinct band profile for most of the primers screened indicating lager extent of alteration in its DNA sequence. Further molecular studies on characterization coupled with sequence information for the genes involved in the fatty acid biosynthetic pathway might lead to the development of molecular markers that would help to increase the efficiency and accuracy of breeding for oil quality. 


\section{Introduction}

Oilseed crops are important sources of energy, both for human consumption and feeding livestock. They are also sources of many non-edible purposes providing raw materials for a wide range of industrial products. The value and utility of an oilseed crop for both nutritional and industrial purposes primarily depends upon the fatty acid composition of the seed oil.

Groundnut oil generally contains $55-60 \%$ monounsaturated fatty acids, 26-28\% polyunsaturated fatty acids and $17-18 \%$ of saturated fatty acids (Ory et al., 1992). The trait for high oleic to linoleic acid ratio $(\mathrm{O} / \mathrm{L})$ in oil seed crops is favored over low $\mathrm{O} / \mathrm{L}$ because it confers health benefits and oil stability. Consuming oils with high levels of oleic acid is believed to be beneficial to human health by reducing low-density lipoproteins, maintaining high-density lipoprotein, slowing down atherosclerosis, and reversing the inhibitory effect of insulin production. Oils containing a high percentage of linoleic acid are prone to oxidation, leading to rancidity, off-flavors, and short shelf- life during seed storage (Vassiliou et al., 2009).

In India, early maturing Spanish Bunch varieties occupy $>70 \%$ area but they are poor in oil quality $(\mathrm{O} / \mathrm{L}$ ratio 1.0$)$, while late maturing spreading varieties are marginally superior $(\mathrm{O} / \mathrm{L}$ ratio $\sim 1.5)$. The available germplasm and breeding lines screened indicated very limited genetic variability for $\mathrm{O} / \mathrm{L}$ ratio (1-3). No genotypes were found in either national (NRCG, Junagadh) or international (ICRISAT, Hyderabad) germplasm repository of groundnut with high $\mathrm{O} / \mathrm{L}$ ratio (40) comparable to two natural mutants (F 435-2 and F 435-2-2), isolated in Florida, USA (Norden et al., 1987). These mutant lines being gene sources for high oleic acid and their derivatives (SunOleic 95R,
SunOleic 97R) are patented. Thus they are not available for their use in international breeding programme. Therefore, it is essential to develop our own genetic sources with this value added trait of high oleic acid for the improvement of oil quality.

The identification of superior genotypes beyond measurable phenotypic values is an indispensable requisite for efficient selection. The utilization of molecular markers allows the breeder to select on the basis of genotypic instead of phenotypic characteristics, thus eliminating environmental effects. Despite the creation of genotypes with modified fatty acid profile in various oilseed crops through induced mutagenesis and interspecific hybridization, the progress towards development of cultivars with desired fatty acids is slow. The breeding efforts are complicated by maternal effects, multiple gene inheritance and large environmental effects (Diepenbrock and Wilson, 1987; Chen and Beversdorf, 1990). This has inspired researchers to develop molecular markers as a more accurate and environmentally insensitive tool to be used in breeding for modified fatty acid profile. A cleaved amplified polymorphic sequence (CAPS) marker has been developed from the FAD2A gene (Chu et al., 2007). Recently, a real-time polymerase chain reaction (PCR) marker has been developed from the $F A D 2 B$ gene (Barkley et al., 2010). This real-time PCR marker has been successfully used to differentiate the mutant allele from wild type allele of the $F A D 2 B$ in breeding materials and cultivars. There is a need to develop a simple and economic PCR assay which can detect both mutant alleles on the $\mathrm{A}$ and $\mathrm{B}$ genomes without using restriction enzymes or fluorescence labels.

The availability of natural variation for high oleic acid in groundnut and significant achievements made in different oilseed crops 
through induced mutagenesis suggest that modification of fatty acid composition can be achieved with concerted efforts and targeted approach through induced mutagenesis in groundnut. Further marker-assisted selection would be particularly valuable for use in improvement of the fatty acid profile of groundnut. In this paper, we report induced variability for fatty acid composition and a simple PCR assay which was used to differentiate the distinct mutants for fatty acid profile from the parents.

\section{Materials and Methods}

\section{Genotypes}

Two Spanish Bunch genotypes of groundnut (Arachis hypogaea L.) viz., GPBD-4 and TPG-41 were selected for mutagenic treatments. The GPBD-4 is an interspecific cross derivative (A. hypogaea $x$ A. cardenasii) in its pedigree (KRG1X ICGV 86885) that contributed for its resistance to two major foliar diseases, late leaf spot and rust. It has desirable pod features, higher shelling outturn, fresh seed dormancy, small seeds with 48-49 per cent oil and $\mathrm{O} / \mathrm{L}$ ratio of 1.66 (Gowda et al., 2002). The TPG-41 is an large seeded confectionary genotype with 48 per cent oil, 25 per cent protein, and higher O/L ratio of 3.23 (Kale et al., 2004).

\section{Mutagen treatment}

Seeds of groundnut genotypes GPBD-4 and TPG-41 were treated with gamma rays $\left({ }^{60} \mathrm{Co}\right)$ and ethyl methane sulphonate (EMS$\mathrm{CH}_{3} \mathrm{CO}_{2} \mathrm{OC}_{2} \mathrm{H}_{5}$ ) (Sigma, USA). Samples of 500 dry, healthy and uniform size seeds were used for mutagenic treatment.

\section{Gamma irradiation}

The seeds with moisture content around 12-14 per cent were exposed to ${ }^{60} \mathrm{Co}$ gamma rays at two different doses i.e., 200 and $300 \mathrm{~Gy}$ at Nuclear Agriculture and Biotechnological Division, Bhabha Atomic Research Station (BARC), Trombay, Mumbai, India. Untreated seeds of the respective cultivars were used as control.

\section{EMS treatment}

The seeds were pre-soaked in distilled water for 8 hours to allow uptake of EMS solution. EMS $(0.5 \%)$ solution was prepared in $0.1 \mathrm{M}$ phosphate buffer (pH-7.0). Pre-soaked seeds were than treated with EMS $(0.5 \%)$ for 6 hours at room temperature in cloth bags. The seeds were continuously shaken by a mechanical shaker. The volume of the solution used was five times higher than the volume of the seeds. Soon after the treatment with the chemical the seeds were thoroughly washed in running tap water for 4 hours and sown in the field plots along with untreated control. The seeds soaked in distill water served as control for EMS treatment.

\section{Material advancement}

The treated seeds were sown at Main Agricultural Research Station of University of Agricultural Sciences, Dharwad $\left(15^{\circ} 13^{\prime} \mathrm{N}\right.$, $75^{\circ} 07^{\prime} \mathrm{E}, 678 \mathrm{~m}$ above MSL) during summer season of 2004 along with control to raise the $\mathrm{M}_{1}$ generation. Seeds were hand dibbled at one seed per hill at a distance of $30 \mathrm{~cm}$ between rows and $10 \mathrm{~cm}$ between plants. All the recommended agronomic and plant protection practices were followed to raise successful crop. The $\mathrm{M}_{2}$ generation of each treatment was raised by growing $\mathrm{M}_{1}$ plant to progeny rows during rainy season of 2004 with a spacing of $30 \mathrm{~cm}$ between rows and 10 $\mathrm{cm}$ between plants. From $\mathrm{M}_{2}$ generation of each mutagen treatment 100 mutant families were chosen randomly and in each family two plants were harvested separately and advanced to $M_{3}$ generation as plant to 
progeny rows sown during rainy season 2005 . The $\mathrm{M}_{3}$ population was not analyzed for fatty acid profile since there was segregation observed for morphological characters and earlier works reported that $\mathrm{M}_{3}$ progenies show wide segregation for fatty acid profile. It was reported that the putative mutants selected for these fatty acids in $\mathrm{M}_{3}$ generation got fixed in $\mathrm{M}_{4} / \mathrm{M}_{5}$ generations (Velasco et al., 1998). Hence in $\mathrm{M}_{3}$ generation again two plants per family were chosen randomly and harvested separately in each treatment and were advanced to $\mathrm{M}_{4}$ generation as plant to progeny rows sown during rainy season 2006. The mutants with stabilized traits harvested separately and randomly selected two mutants per family in all the treatments (200plants/treatment) along with the controls were used for fatty acid analysis following the procedure described by Young and Waller (1972). The distinct mutants identified in $\mathrm{M}_{4}$ generation were advanced to $\mathrm{M}_{5}$ during rainy season 2007 and mutants with consistent fatty acid profile in $\mathrm{M}_{4}$ and $\mathrm{M}_{5}$ were subjected to PCR assay.

\section{Fatty acid analysis}

Randomly chosen samples of unshelled pods were obtained from each mutant line and only sound mature seeds were used for fatty acid analysis. Fatty acid analysis of mutant population was done by gas chromatography (GC) using a modification of the method of Young and Waller (1972). A gas chromatograph, model GC-2010 (Shimadzu, Kyoto, Japan) equipped with automatic sample injector AOC-20i, flame ionization detector and fitted with a narrow bore capillary column; Rtx-wax (film thickness$0.25 \mu \mathrm{m}$; I. D. $-0.25 \mathrm{~mm}$; length-30 m) was used to separate methyl esters. The initial column temperature was set at $170^{\circ} \mathrm{C}$ and held for 3 minutes, then programmed at an increase of $10^{\circ} \mathrm{C}$ per minute to a final temperature of $230^{\circ} \mathrm{C}$, at which it was held for
1 minute. Injector and detector temperatures were both set at $250^{\circ} \mathrm{C}$. The flow rates for nitrogen (carrier gas), hydrogen and air were 45, 40 and $400 \mathrm{ml}$ per minute respectively. A split ratio of 10:1 was employed and $1 \mu \mathrm{l}$ of sample was injected using an auto sampler. The fatty acid methyl esters were identified by a comparison of retention time to an standard methyl ester fatty acid mixtures (Sigma, Aldrich). Concentration of each fatty acid were recorded by normalization of peak areas and reported as per cent of particular fatty acid (Fig. 2).

\section{PCR amplification}

A total of 22 stabilized mutants, distinct for fatty acid profile along with the parents (Table 1) were used for PCR assay using 20 decamer primers to analyze the variation in these mutants at the molecular level compared to their respective parents. DNA template was prepared by isolation and purification of genomic DNA from young leaves of 22 mutants with modified fatty acid profile and parental genotypes, GPBD-4 and TPG-41 by following CTAB method (Saghai-Maroof et al., 1984). In PCR reaction mixture, 100ng template DNA was used in total $20 \mu \mathrm{l}$ reaction volume containing $250 \mu \mathrm{M}$ of each dNTP, 5 pico moles of each primer, $1 \mathrm{X}$ Taq buffer, $15 \mathrm{mM} \mathrm{MgCl}_{2}$ and $1 \mathrm{U}$ Taq DNA polymerase (M/s Bangalore Genei Pvt. Ltd., Bangalore). PCR was run in a thermo cycler (Model: Corbet, Australia). The DNA was initially denatured at $94^{\circ} \mathrm{C}$ for 5 minutes followed by 37 cycles each of $94^{\circ} \mathrm{C}$ for 2 minutes, $36^{\circ} \mathrm{C}$ for 1 minutes and $72^{\circ} \mathrm{C}$ for 2 minute. The final extension of 10 minute at $72^{\circ} \mathrm{C}$ was given to amplify partly amplified sequences.

\section{Results and Discussion}

Nutritional concerns, functionality in food manufacturing and the need for high stability 
and extended shelf life had a tremendous impact on developing and commercializing modified oilseeds, so far. Induced mutation is one of the most widely used techniques for creating additional diversity in seed oil quality. Mutations, both spontaneously and induced have been eminently successful in changing the fatty acid composition of several oilseed crops viz., sunflower (Osorio et al., 1995), rapeseed (Rucker and Robbelen, 1995) and groundnut (Suvendu and Anand, 2010).

In the present work as a result of mutagenic treatments, a greater magnitude of induced variability was recorded for palmitic acid, oleic acid and linoleic acid contents which are evident from (a) significant differences in mean fatty acid contents between the mutagenic treatments and also in comparison to parent (b) increased range values (Table 1). Similarly in soybean Archana et al., (2007) reported greater induced variation for stearic acid, oleic acid and linoleic acid content.

The mutant populations in GPBD-4 recorded significantly reduced mean palmitic acid content, increased oleic acid and reduced linoleic acid in $\mathrm{M}_{5}$ generations compared to parent. Mutagen treatment with EMS (0.5\%) resulted in higher reduction in palmitic acid $(7.98 \%)$ compared to parent (10.02\%). Gamma rays treatment at 300 Gy recorded significantly higher increased mean oleic acid (57.03\%) and reduced linoleic acid (20.16\%) over parent $(50.87 \%, 29 \%)$. On the contrary in TPG-41 the mutant populations derived from 300 Gy treatment recorded significantly reduced palmitic acid $(8.03 \%)$ and on par with parent for oleic acid and linoleic acid $(58.65 \%$, 20.70\%) whereas the 200 Gy mutagen treatment recorded significantly reduced oleic acid (48.32\%) and increased linoleic acid (25.22\%) compared to control $(60.20 \%, 20.56 \%)$ (Table 1). Though the two genotypes used in this study showed differential response with respect to mean fatty acid contents however they were similar with respect to magnitude of induced variability. The mutagen treatments could result in wide range values for oleic acid (39.01-75.16\%), linoleic acid (9.01-37.82\%) and $\mathrm{O} / \mathrm{L}$ ratio (1.03-8.34) in GPBD-4 mutant populations. The range of variation recorded in mutagen treated populations of TPG-41 for oleic acid (37.40-68.97\%), linoleic acid (13.60-38.33\%) and $\mathrm{O} / \mathrm{L}$ ratio (0.95-5.38) (Table 1). There are reports of increasing variability in fatty acid composition by mutagenic treatments. Velasco et al., (1998) reported that the analysis of the fatty acid composition of the oil in Ethiopian mustard showed a considerable increase in the range of variation of several fatty acids with the largest increased variability was found for oleic acid and erucic acid content compared to parental line.

The range for fatty acid percentages found in mutant population of two genotypes included in this study exceeded the ranges reported in various groundnut materials. Hammond et al., (1997) analyzed 732 groundnut plant introductions for fatty acid composition and oleic acid and linoleic acid ranged from 31.5 to 60.2 per cent and 19.9 to 45.4 per cent respectively.

The majority of groundnut cultivars average 55 per cent oleic acid and 25 per cent linoleic acid (Knauft et al., 1993). The ranges recorded in present study almost reached the higher values reported by Norden et al., (1987) These reports clearly indicate that significant genetic improvement for oil quality in groundnut that was not achieved hitherto by simple recombination either by using wild species or cultivated ones could be achieved by creation of variability by induced mutagenesis. Hence the wide range of induced variability observed in the present study is really encouraging for future oil quality improvement breeding programmes. 
Table.1 Induced variability for fatty acid composition in mutant population of groundnut at $\mathrm{M}_{5}$ generation

\begin{tabular}{|c|c|c|c|c|}
\hline Fatty acids & Genotypes & Treatments & Mean & Range \\
\hline \multirow{8}{*}{$\begin{array}{l}\text { Palmitic } \\
\text { (C16:0) }\end{array}$} & \multirow{4}{*}{$\begin{array}{c}\text { GPBD-4 } \\
(0.87)\end{array}$} & EMS $(0.5 \%)$ & $7.98^{c}$ & $6.83-11.86$ \\
\hline & & $200 \mathrm{~Gy}$ & $8.83^{\mathrm{b}}$ & $8.00-10.55$ \\
\hline & & $300 \mathrm{~Gy}$ & $9.01^{\mathrm{b}}$ & $7.88-10.60$ \\
\hline & & Control & $10.02^{\mathrm{a}}$ & $9.13-10.85$ \\
\hline & \multirow{4}{*}{$\begin{array}{c}\text { TPG-41 } \\
(0.74)\end{array}$} & EMS $(0.5 \%)$ & $9.03^{\mathrm{a}}$ & 8.44-11.38 \\
\hline & & $200 \mathrm{~Gy}$ & $9.36^{\mathrm{a}}$ & $8.06-12.45$ \\
\hline & & $300 \mathrm{~Gy}$ & $8.03^{b}$ & $7.86-10.36$ \\
\hline & & Control & $9.70^{\mathrm{a}}$ & $8.82-10.45$ \\
\hline \multirow{8}{*}{ Oleic (C18:1) } & \multirow{4}{*}{$\begin{array}{c}\text { GPBD-4 } \\
(3.16)\end{array}$} & EMS $(0.5 \%)$ & $53.21^{\mathrm{b}}$ & $39.01-75.16$ \\
\hline & & $200 \mathrm{~Gy}$ & $54.47^{b}$ & $48.17-64.81$ \\
\hline & & $300 \mathrm{~Gy}$ & $57.03^{\mathrm{a}}$ & $47.80-68.21$ \\
\hline & & Control & $50.76^{c}$ & $48.80-52.67$ \\
\hline & \multirow{4}{*}{$\begin{array}{c}\text { TPG-41 } \\
(1.98)\end{array}$} & EMS $(0.5 \%)$ & $53.46^{\mathrm{b}}$ & $45.20-65.84$ \\
\hline & & $200 \mathrm{~Gy}$ & $48.32^{c}$ & $37.40-64.55$ \\
\hline & & $300 \mathrm{~Gy}$ & $58.65^{\mathrm{a}}$ & 49.24-68.97 \\
\hline & & Control & $60.20^{\mathrm{a}}$ & $57.41-62.60$ \\
\hline \multirow{8}{*}{$\begin{array}{l}\text { Linoleic } \\
\text { (C18:2) }\end{array}$} & \multirow{4}{*}{$\begin{array}{c}\text { GPBD-4 } \\
(2.91)\end{array}$} & EMS $(0.5 \%)$ & $23.04^{b}$ & $9.01-37.82$ \\
\hline & & $200 \mathrm{~Gy}$ & $21.03^{b c}$ & $15.20-28.97$ \\
\hline & & $300 \mathrm{~Gy}$ & $20.16^{c}$ & $12.73-32.41$ \\
\hline & & Control & $28.21^{\mathrm{a}}$ & $26.62-29.55$ \\
\hline & \multirow{4}{*}{$\begin{array}{c}\text { TPG-41 } \\
(1.73)\end{array}$} & $\operatorname{EMS}(0.5 \%)$ & $22.03^{b}$ & $15.23-34.23$ \\
\hline & & $200 \mathrm{~Gy}$ & $25.22^{\mathrm{a}}$ & 16.53-38.33 \\
\hline & & $300 \mathrm{~Gy}$ & $20.70^{b}$ & $13.60-30.40$ \\
\hline & & Control & $20.56^{b}$ & $18.01-22.68$ \\
\hline \multirow{8}{*}{$\mathrm{O} / \mathrm{L}$ ratio } & \multirow{4}{*}{$\begin{array}{c}\text { GPBD-4 } \\
(0.43)\end{array}$} & EMS $(0.5 \%)$ & $3.13^{\mathrm{a}}$ & $1.03-8.34$ \\
\hline & & $200 \mathrm{~Gy}$ & $2.32^{\mathrm{b}}$ & $1.73-4.26$ \\
\hline & & $300 \mathrm{~Gy}$ & $2.58^{\mathrm{b}}$ & $1.41-5.35$ \\
\hline & & Control & $1.76^{\mathrm{c}}$ & $1.72-1.82$ \\
\hline & \multirow{4}{*}{$\begin{array}{c}\text { TPG-41 } \\
(0.36)\end{array}$} & EMS $(0.5 \%)$ & $2.73^{\mathrm{b}}$ & $1.32-4.14$ \\
\hline & & $200 \mathrm{~Gy}$ & $2.38^{\mathrm{b}}$ & $0.95-3.91$ \\
\hline & & $300 \mathrm{~Gy}$ & $3.38^{\mathrm{a}}$ & $1.56-5.38$ \\
\hline & & Control & $2.91^{\mathrm{b}}$ & $2.75-3.06$ \\
\hline
\end{tabular}

Values in the parenthesis below the genotype indicates CD (1\%)

* Values with same superscript are statistically on par at $1 \%$ level of significance 
Table. 2 Polymphism showed by 20 RAPD primers in 22 mutants having distinct fatty acid profile

\begin{tabular}{|c|c|c|c|c|}
\hline Sl. No. & Primer & $\begin{array}{c}\text { No. of } \\
\text { amplified } \\
\text { fragments }\end{array}$ & $\begin{array}{c}\text { No. of polymorphic } \\
\text { fragments }\end{array}$ & $\begin{array}{c}\text { Percent } \\
\text { polymorphism }\end{array}$ \\
\hline 1 & OPA-12 & 6 & 2 & 33.00 \\
\hline 2 & OPA-15 & 8 & 6 & 75.00 \\
\hline 3 & OPA-16 & 2 & 0 & 0.00 \\
\hline 4 & OPA-18 & 3 & 0 & 0.00 \\
\hline 5 & OPA-20 & 6 & 3 & 50.00 \\
\hline 6 & OPAT-01 & 3 & 1 & 33.33 \\
\hline 7 & OPAT-02 & 10 & 8 & 80.00 \\
\hline 8 & OPAT-03 & 7 & 4 & 57.14 \\
\hline 9 & OPAT-04 & 5 & 3 & 60.00 \\
\hline 10 & OPAT-06 & 11 & 8 & 72.72 \\
\hline 11 & OPAT-08 & 12 & 6 & 50.00 \\
\hline 12 & OPAT-09 & 10 & 7 & 70.00 \\
\hline 13 & OPB-08 & 5 & 2 & 40.00 \\
\hline 14 & OPB-09 & 15 & 9 & 60.00 \\
\hline 15 & OPB-13 & 6 & 3 & 50.00 \\
\hline 16 & OPC-09 & 14 & 8 & 57.14 \\
\hline 17 & OPC-13 & 3 & 1 & 33.33 \\
\hline 18 & OPF-04 & 7 & 3 & 42.86 \\
\hline 19 & OPJ-06 & 8 & 5 & 62.50 \\
\hline \multirow[t]{3}{*}{20} & OPK-14 & 10 & 7 & 70.00 \\
\hline & Total & 151 & 86 & - \\
\hline & Average & 7.55 & 4.3 & 49.85 \\
\hline
\end{tabular}


Table.3 Similarity matrix of mutants having distinct fatty acid profile based on RAPD profile of 20 primers

\begin{tabular}{|c|c|c|c|c|c|c|c|c|c|c|c|c|c|c|c|c|c|c|c|c|c|c|c|c|}
\hline Mutants & $\begin{array}{l}\text { G2- } \\
214\end{array}$ & $\begin{array}{c}\text { GE } \\
- \\
113\end{array}$ & $\begin{array}{c}\text { G3- } \\
46\end{array}$ & $\begin{array}{l}\text { GE } \\
-97\end{array}$ & $\begin{array}{l}\text { G3- } \\
212\end{array}$ & $\begin{array}{l}\text { G3- } \\
109\end{array}$ & $\begin{array}{c}\text { GE } \\
-\mathbf{- 3 4}\end{array}$ & $\begin{array}{c}\text { G3- } \\
15\end{array}$ & $\begin{array}{c}\text { G3- } \\
77\end{array}$ & $\begin{array}{l}\text { G3- } \\
233\end{array}$ & $\begin{array}{c}\text { GE } \\
- \\
273\end{array}$ & $\begin{array}{l}\text { GE } \\
-75\end{array}$ & $\begin{array}{c}\text { GE } \\
- \\
125\end{array}$ & $\begin{array}{l}\text { T3- } \\
109\end{array}$ & $\begin{array}{c}\text { G2- } \\
75\end{array}$ & $\begin{array}{l}\text { G3- } \\
217\end{array}$ & $\begin{array}{l}\text { G3- } \\
263\end{array}$ & $\begin{array}{l}\text { GE- } \\
270\end{array}$ & $\begin{array}{c}\text { G3- } \\
19\end{array}$ & T3-6 & $\begin{array}{l}\text { GE- } \\
281\end{array}$ & $\begin{array}{l}\text { T2- } \\
92\end{array}$ & $\begin{array}{c}\text { TPG } \\
-41\end{array}$ & $\begin{array}{c}\text { GPBD } \\
-4\end{array}$ \\
\hline G2-214 & 1.00 & & & & & & & & & & & & & & & & & & & & & & & \\
\hline GE-113 & 0.86 & 1.00 & & & & & & & & & & & & & & & & & & & & & & \\
\hline G3-46 & 0.93 & 0.90 & 1.00 & & & & & & & & & & & & & & & & & & & & & \\
\hline GE-97 & 0.88 & 0.94 & 0.93 & 1.00 & & & & & & & & & & & & & & & & & & & & \\
\hline G3-212 & 0.92 & 0.91 & 0.95 & 0.91 & 1.00 & & & & & & & & & & & & & & & & & & & \\
\hline G3-109 & 0.90 & 0.90 & 0.89 & 0.88 & 0.94 & 1.00 & & & & & & & & & & & & & & & & & & \\
\hline GE-34 & 0.92 & 0.90 & 0.91 & 0.92 & 0.93 & 0.94 & 1.00 & & & & & & & & & & & & & & & & & \\
\hline G3-15 & 0.90 & 0.89 & 0.92 & 0.91 & 0.93 & 0.91 & 0.92 & 1.00 & & & & & & & & & & & & & & & & \\
\hline G3-77 & 0.89 & 0.92 & 0.91 & 0.95 & 0.91 & 0.89 & 0.92 & 0.91 & 1.00 & & & & & & & & & & & & & & & \\
\hline G3-233 & 0.91 & 0.89 & 0.92 & 0.92 & 0.93 & 0.93 & 0.93 & 0.92 & 0.92 & 1.00 & & & & & & & & & & & & & & \\
\hline GE-273 & 0.66 & 0.71 & 0.71 & 0.72 & 0.68 & 0.64 & 0.66 & 0.68 & 0.69 & 0.65 & 1.00 & & & & & & & & & & & & & \\
\hline GE-75 & 0.91 & 0.91 & 0.92 & 0.93 & 0.93 & 0.92 & 0.94 & 0.92 & 0.92 & 0.91 & 0.66 & 1.00 & & & & & & & & & & & & \\
\hline GE-125 & 0.94 & 0.86 & 0.93 & 0.88 & 0.92 & 0.90 & 0.90 & 0.89 & 0.88 & 0.91 & 0.64 & 0.91 & 1.00 & & & & & & & & & & & \\
\hline T3-109 & 0.89 & 0.87 & 0.91 & 0.92 & 0.88 & 0.83 & 0.87 & 0.86 & 0.88 & 0.87 & 0.72 & 0.89 & 0.88 & 1.00 & & & & & & & & & & \\
\hline G2-75 & 0.85 & 0.89 & 0.87 & 0.89 & 0.89 & 0.88 & 0.88 & 0.83 & 0.87 & 0.84 & 0.70 & 0.90 & 0.84 & 0.88 & 1.00 & & & & & & & & & \\
\hline G3-217 & 0.87 & 0.90 & 0.93 & 0.92 & 0.89 & 0.85 & 0.87 & 0.86 & 0.90 & 0.89 & 0.69 & 0.89 & 0.87 & 0.88 & 0.87 & 1.00 & & & & & & & & \\
\hline G3-263 & 0.89 & 0.89 & 0.94 & 0.93 & 0.93 & 0.88 & 0.90 & 0.89 & 0.91 & 0.92 & 0.69 & 0.90 & 0.90 & 0.90 & 0.85 & 0.92 & 1.00 & & & & & & & \\
\hline GE-270 & 0.88 & 0.83 & 0.88 & 0.84 & 0.89 & 0.88 & 0.86 & 0.86 & 0.85 & 0.88 & 0.66 & 0.87 & 0.88 & 0.86 & 0.81 & 0.84 & 0.88 & 1.00 & & & & & & \\
\hline G3-19 & 0.92 & 0.90 & 0.92 & 0.90 & 0.96 & 0.93 & 0.91 & 0.92 & 0.89 & 0.92 & 0.65 & 0.94 & 0.91 & 0.88 & 0.88 & 0.89 & 0.92 & 0.92 & 1.00 & & & & & \\
\hline T3-6 & 0.90 & 0.89 & 0.92 & 0.93 & 0.90 & 0.88 & 0.90 & 0.88 & 0.91 & 0.89 & 0.69 & 0.93 & 0.89 & 0.92 & 0.89 & 0.92 & 0.94 & 0.87 & 0.91 & 1.00 & & & & \\
\hline GE-281 & 0.92 & 0.86 & 0.93 & 0.90 & 0.90 & 0.87 & 0.89 & 0.87 & 0.87 & 0.88 & 0.66 & 0.93 & 0.93 & 0.89 & 0.88 & 0.91 & 0.90 & 0.87 & 0.91 & 0.91 & 1.00 & & & \\
\hline $\mathrm{T} 2-92$ & 0.89 & 0.87 & 0.91 & 0.90 & 0.89 & 0.87 & 0.87 & 0.85 & 0.87 & 0.87 & 0.68 & 0.90 & 0.89 & 0.90 & 0.89 & 0.89 & 0.89 & 0.87 & 0.90 & 0.93 & 0.92 & 1.00 & & \\
\hline TPG-41 & 0.92 & 0.87 & 0.92 & 0.87 & 0.91 & 0.91 & 0.91 & 0.90 & 0.87 & 0.89 & 0.69 & 0.92 & 0.91 & 0.87 & 0.91 & 0.86 & 0.89 & 0.87 & 0.93 & 0.89 & 0.91 & 0.90 & 1.00 & \\
\hline GPBD-4 & 0.88 & 0.84 & 0.90 & 0.88 & 0.87 & 0.85 & 0.89 & 0.88 & 0.85 & 0.85 & 0.68 & 0.90 & 0.88 & 0.90 & 0.85 & 0.87 & 0.88 & 0.88 & 0.91 & 0.88 & 0.89 & 0.87 & 0.90 & 1.00 \\
\hline
\end{tabular}


Fig.1 Dendrogram of the mutants having desirable fatty acid profile based on RAPD profile of 20 primers

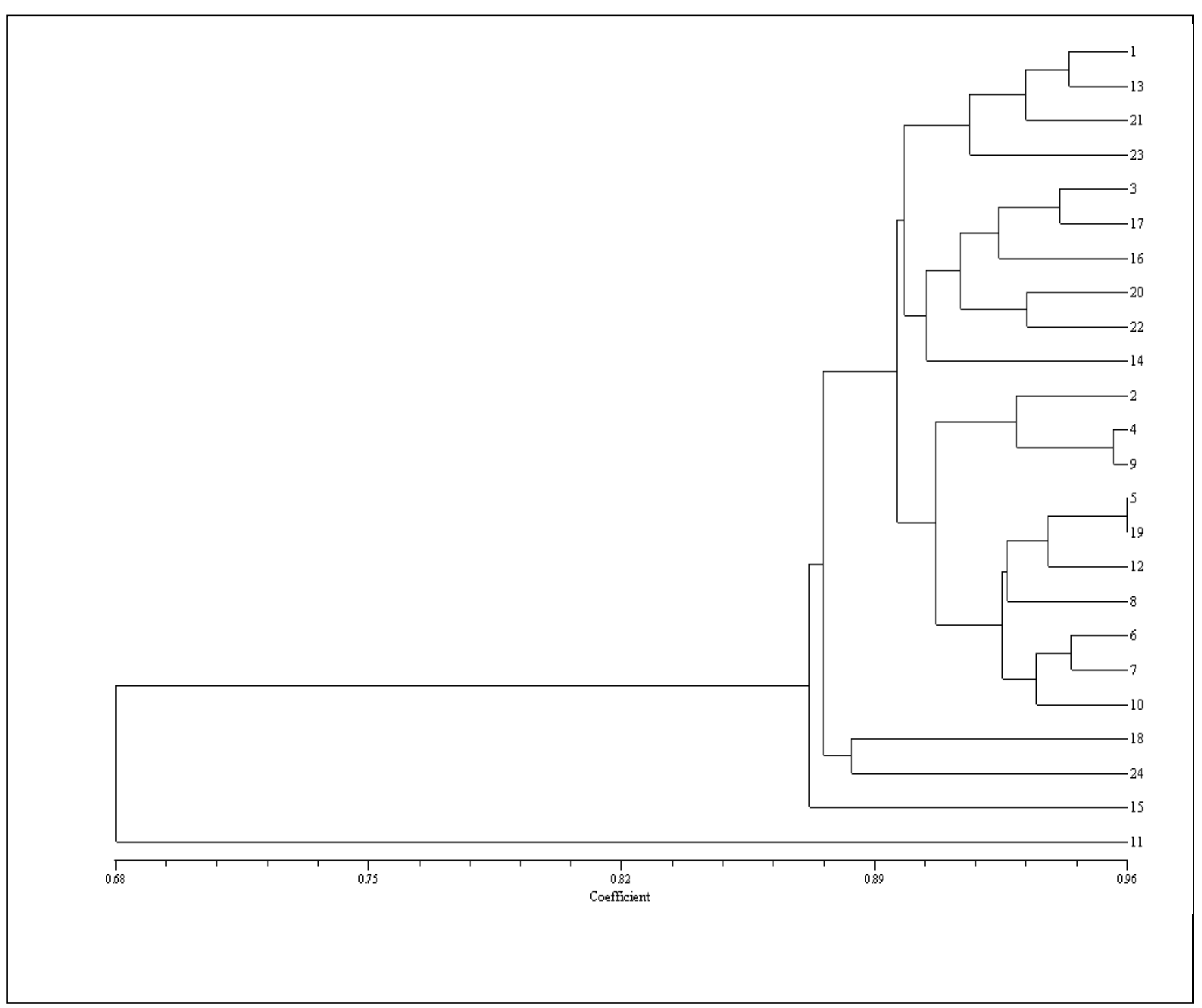

1. $\mathrm{G} 2-214$

2. GE-113

3. G3-46

4. GE-97

5. G3-212

6. G3-109

7. GE-34

8. G3-15

9. G3-77

10. G3-233

11. GE-273

12. GE-75

13. GE-125

14. TG3-109

15. G2-75

16. G3-217

17. G3-263

18. GE-270

19. G3-19

20. TG3-6

21. GE-281

22. TG2-92

23. TPG-41

24. GPBD-4 
Fig.2 PCR amplified polymorphism exhibited by different mutants by OPJ 06 primer

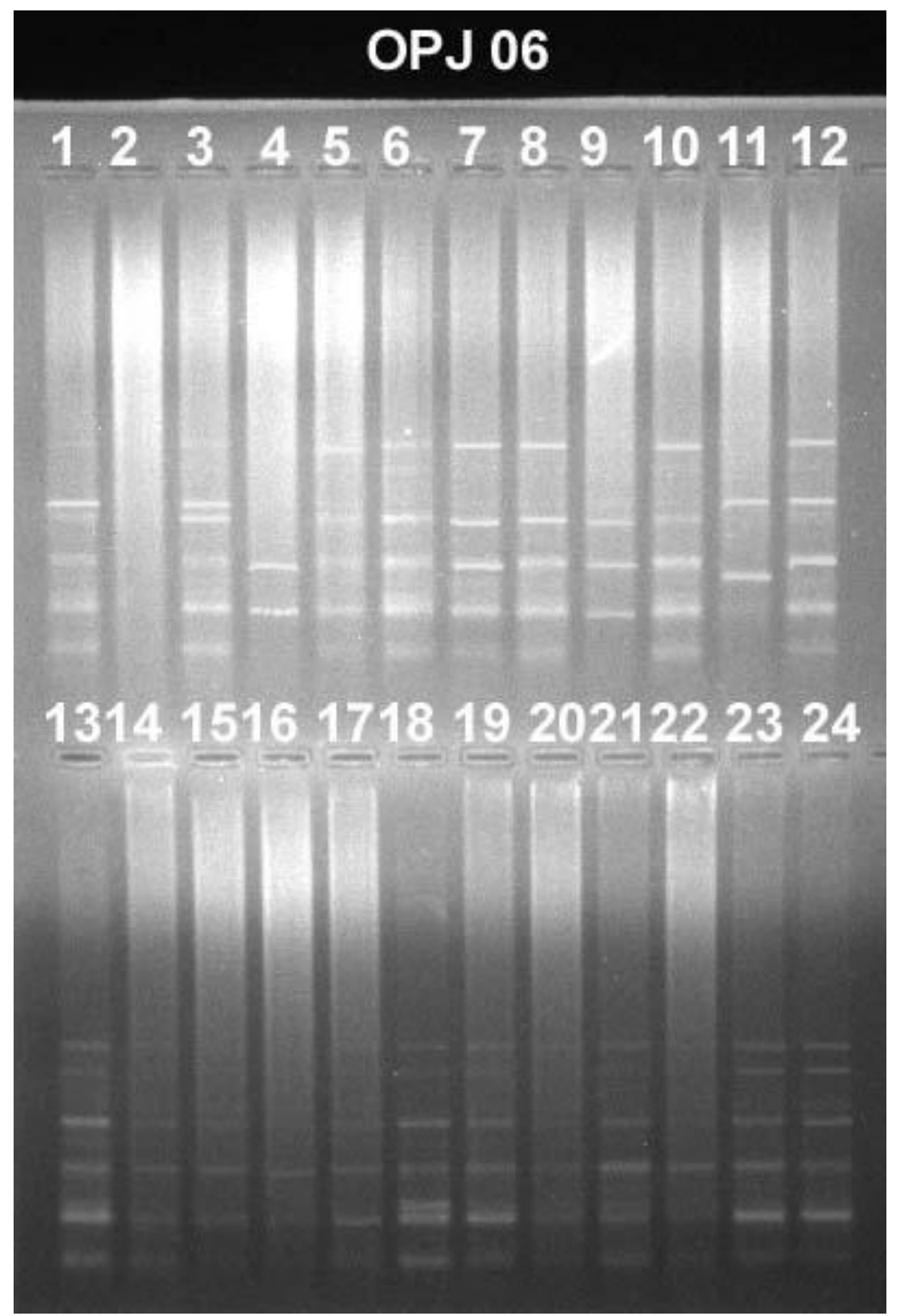

(1. G2-214; 2. GE-113; 3. G3-46; 4. GE-97; 5. G2-212; 6. G3-109; 7. GE-34; 8. G3-15; 9. G3-77; 10. G3-233; 11. GE-273; 12. GE-75; 13. GE-125; 14. T3-109; 15. G2-75; 16. G3-217; 17. G3-263; 18. GE-270; 19. G3-19; 20. T36; 21. GE-281; 22. T2-92; 23. TPG-41; 24. GPBD-4)

Mutagen treatment with EMS $(0.5 \%)$ in GPBD-4 and gamma rays at 300 Gy in TPG41 were found to be most effective in increasing the variability for the fatty acid composition in desirable direction (increased $\mathrm{O} / \mathrm{L}$ ratio). Treatments of EMS in higher concentrations as well as combined treatment of gamma irradiation and EMS were reported to be effective in increasing the variability for the fatty acid content in soybean oil (Archana et al., 2007). The effectiveness of obtaining a novel genetic variation for a given trait using mutagenesis depends on the mutagenic treatment, efficient screening technique and 
also vary probably, on the genetic background of the original phenotype. Such a differential response of the genotypes and mutagenic treatments in inducing variability for fatty acids was also reported in Ethiopian mustard (Velasco et al., 1998).

Twenty two stabilized mutants with distinct fatty acid profile compared to parents were selected and subjected to molecular analysis. The RAPD assay of mutants with distinct fatty acid profile using 20 random primers revealed limited polymorphism $(49.85 \%)$. A total of number of 151 DNA fragments were amplified by 20 RAPD primers with an average frequency of 7.55 amplified products per primer. Eighty six $(49.85 \%)$ of the total 151 fragments produced were polymorphic with an average of 4.30 polymorphic amplicons per primer. Number of amplified fragments varied with the primers evaluated ranging from only two (OPA-16) to 15 fragments (OPB-09). Two primers (OPA-16 and OPA-18) produced amplification products that were monomorphic across all 24 genotypes. The remaining 18 primers produced polymorphic amplicons that ranged from one, with OPAT-01 and OPC-13 $(33.33 \%)$ to nine with OPB-09 $(60.00 \%)$. Primer OPAT-02 could produce highest per cent polymorphism (80.00) (Table 2).

The similarity coefficient ranged from 0.84 to 0.96 (Table 3). The highest genetic diversity was observed between GE-273 with GE-125 and G3-109 at Sij 0.64. The maximum similarity was observed between G3-19 and G2-212 sharing a similarity coefficient of 96 per cent. The dendrogram shows seven main distinct clusters (Fig. 1). Except mutant GE273 , all other genotypes made a separate big cluster at 0.85 similarity coefficient. Mutant GE-270 and GPBD-4 made an independent cluster at 0.88 similarity coefficient. The two parents of the mutants (GPBD-4 and TPG-41) were grouped into different clusters. Mutants with increased $\mathrm{O} / \mathrm{L}$ ratio in GPBD-4 (GE-113, GE-97 and G3-77) and TPG-41 (T3-109, T36 and T2-92) formed separate clusters with mutant recording highest $\mathrm{O} / \mathrm{L}$ ratio i.e. GE113 and TG3-109 forming solitary cluster in their respective groups. Mutant GE-273 which exhibited reduced $\mathrm{O} / \mathrm{L}$ ratio compared to parent GPBD-4 formed a solitary cluster at Sij 0.68 and it was highly diverse from all other mutants and parent (Fig. 1 and 2).

RAPD analysis could detect limited polymorphism in the present material studied as indicated by some earlier workers (Halward et al., 1992; Dwivedi et al., 2001). A simple PCR assay was developed by designing allele-specific primers and alternating annealing temperatures which can be used to detect mutant and wild-type alleles of FAD2 on both the A and B genomes of peanut (Zhenbang et al., 2010). Javidfar et al., (2006) in oilseed rape reported association of RAPD markers with low and high oleic acid content.

Low oleic and high linoleic acid mutant GE273 (1.16) differed from the parent (1.76) and other mutants and for most of the primers it showed a very distinct band profile (Fig. 2), indicating lager extent of alteration in its DNA sequence. The specific amplified fragment has to be sequenced to know specific change at DNA level and find out whether this differentiation in the mutant has really occurred due to mutation in genes governing oleic and linoleic acid. The sequence information could be used to develop STS (Sequence Tagged Site) markers that could be employed to differentiate other genotypes as well. Comparisons of encoding sequences from the high and low oleic acid genotypes revealed variation in several single nucleotide polymorphisms (SNPs) (Lopez et al., 2000). Molecular characterization coupled with sequence information for the genes involved in the fatty acid pathway might lead 
to the development of molecular markers useful for accelerating selection of high $\mathrm{O} / \mathrm{L}$ types.

\section{References}

Archana, P., Taware, S. P. and Oak, M. D. 2007. Improvement of oil quality in soybean (Glycine max (L.) Merrill) by mutation breeding. J. American Oilseed Chem., 84: 1117-1124.

Barkley, N. A., Chenault-Chamberli K. D., Wang M.L., Pittman, R. N. 2010. Development of a real time PCR genotyping assay to identify high oleic acid peanuts (Arachis hypogaea L.). Mol Breeding. 25: 541-548.

Chen, J. and Beversdorf, D. 1990. Fatty acid inheritance in microspore-derived populations of spring rapeseed (Brasica napus L.). Theoret. Appl. Genet., 80: 465-469.

Chu, Y., Ramos, L., Holbrook, C. C., OziasAkins P. 2007. Frequency of a loss-offunction mutation in oleoyl-PC desaturase (ahFAD2A) in the mini-core of the U.S. peanut germplasm collection. Crop Sci., 47:2372-2378

Diepenbrock, W. and Wilson, R. F., 1987, Genetic regulation of linolenic acid concentration in rapeseed. Crop Sci., 27: $75-77$.

Dwivedi, S. L., Gurtu, S., Chandra, S., Yuejin, W. and Nigam, S. N. 2001. Assessment of genetic diversity among selected groundnut germplasm. 1: RAPD analysis. Plant Breed., 120: 345349.

Gowda, M.V.C., B.N. Motagi, G.K. Naidu, S.B. Diddimani, and R. Sheshagiri. 2002. GPBD 4: A Spanish bunch groundnut genotype resistant to rust and late leaf spot. Int. Arachis Newslet., 22:29-32.

Halward, T. M. Staker, H. T. Larue, E. A. and Kochert, G. A. 1992. Use of single- primer DNA amplifications in genetic studies of peanut (Arachis hypogaea L.). Plant Molecul. Biol., 18: 315-325.

Hammond, E. G., Duvick, D., Wang. T., Dodo, H. and Pittman, R. N. 1997. Survey of the fatty acid composition of peanut (Arachis hypogaea) germplasm and characterization of their epoxy and eicosenoic acids. J. American Oil Chem. Soc., 74: 1235-1239.

Javidfar, F., Ripley, V. L., Roslinsky, V., Zeinali, H. and Abdmishani, C. 2006. Identification of molecular markers associated with oleic and linoleic acid in spring oilseed rape (Brassica napus). Plant Breed., 125: 65-71.

Kale, D.M, Murty, G.S.S and Badigannavar, A.M. 2004. TPG-41: a new largeseeded groundnut variety released in India. International Arachis Newsletter. 24: 21-22.

Knauft, D. A., Moore, K. M. and Gorbet, D. W. 1993. Further studies on the inheritance of fatty acid composition in peanut. Peanut Sci., 20: 74-76.

Lopez, Y., Nadaf, H. L., Smith, O. D. and Connell, J. P. 2000. Isolation and characterization of the $\Delta^{12}$ - fatty acid desturase in peanut (Arachis hypogaea L.) and search for polymorphism for the high oleate trait in Spanish market-type lines. Theoret. Appl. Genet., 101: 11311138.

Norden A. J., Gorbet D. W., Knauft D.A., Young C.T. 1987. Variability in oil quality among peanut genotypes in the Florida breeding program. Peanut Sci., 4:7-11

Ory, R. L., Crippen, K. L. and Lovegren, N. V. 1992. Off flavors in foods and beverages, Elsevier Science Publishers, New York. pp. 57-75.

Osorio, J. J., Fernandez-Martinez, M., Mancha and Graces, R. 1995. Mutant sunflowers with high concentration of saturated fatty acids in the oil. Crop 
Sci., 35: 739-742.

Rucker, B., and Robblen, G. 1997. Mutants of Brassica napus with altered seed lipid fatty acid composition. In: Proceedings of $12^{\text {th }}$ International Symposium on Plant Lipids. Kulwer Academic Publishers, Dordrecht. pp. 316-318.

Saggai-Maroof, M. A, Soliman, K. M., Jorgensen, R. A. and Allard, R. W. 1984. Ribosomal DNA spacer length polymorphism in barley. Mendelian inheritance, chromosomal location and population dynamics. Proceed. Nat. Acad. Sci., USA, 81: 8014-8018.

Suvendu, M. and Anand M. B., 2010. Induction of genetic variability for fatty acid composition in a large-seeded groundnut variety through induced mutagenesis. An Open Access Journal published by ICRISAT, 8: 1-4.

Vassiliou, E.K., Gonzalez A., Garcia C., Tadros J. H., Chakraborty G, Toney
J.H. 2009. Oleic acid and peanut oil high in oleic acid reverse the inhibitory effect of insulin production of the inflammatory cytokine TNF- $\alpha$ both in vitro and in vivo system. Lipids Health Disease. 8: 25-31

Velasco, L. Fernandz-Martinz, J. M. and De Haro, A., 1998. Increasing erucic acid content in Ethiopian mustard through mutation breeding, Plant Breed., 117: 85-87.

Young, C. T. and Waller, G. R., 1972. Rapid oleic/linoleic microanalytical procedure for peanuts. J. Agril. Food Chem., 20: 1116-1118.

Zhenbang, C., Ming L. W., Noelle A. B., and Roy N. P. 2010. A Simple AlleleSpecific PCR Assay for Detecting FAD2Alleles in Both A and B Genomes of the Cultivated Peanut for HighOleate Trait Selection. Plant Mol Biol Rep., 28: 542-548.

\section{How to cite this article:}

Kavera Biradar, Mallikarjun Kenganal and Nadaf, H.L. 2017. Phenotypic and Molecular dissection of Induced Groundnut Mutants for Fatty Acid Profile. Int.J.Curr.Microbiol.App.Sci. 6(12): 3056-3068. doi: https://doi.org/10.20546/ijcmas.2017.612.357 